\title{
Handi kollektiivne põdraohverdus Usk, olemasolu ja kultuuriline püsimajäämine tänapäeva Siberis ${ }^{1}$
}

\author{
Olga Balalajeva, Andrew Wiget
}

\begin{abstract}
Teesid
Käesolevas kirjutises kirjeldame üksikasjalikult Vene Föderatsiooni Handi-Mansi autonoomse ringkonna Surguti rajoonis elavate idahantide põdra ühisohverdamist (myr), mille tunnistajaiks olime 1992. aasta märtsis. Artiklis selgitame, kuidas myri struktuur on vastavuses handi usundilise süsteemiga ja kuidas määratletakse selle keskne ülesanne - toidu ja majandusliku heaolu kindlustamine. Leiame tõlgendusi paljudele ohverdusrituaali joontele, mis annavad tunnistust handi usulise praktika kohanduvast iseloomust, eriti kultusspetsialistide tegevuse ja rolli määratlemise osas. Lõppjäreldus: põdraohverdamine jätkub hoolimata välisest vastusurvest, sest see lavastab handi maailma põhisuhteid ja annab selles osalejatele lootuse säilitada usund ja jätkata põliseid kombeid.
\end{abstract}

Märksõnad: handi rahvausund, šamanism, ohverdamine, mütoloogia, rituaal, hingekujutelm

Nõukogude etnoloogiakirjandus propageeris tihti Siberi algupäraste usundite väljasuremist. Näiteks ei olnud sugugi ebatavalised alljärgnevad väited.

Šamanism on mänginud äärmiselt negatiivset osa Siberi rahvaste ajaloos [---] šamaanid tegutsesid käsikäes põliselanikkonda valitsevate kildkondadega. Nad põhjustasid tohutut majanduslikku kahju, nõudes pidevalt vereohvreid, mis tähendas koera, põdra või muu jahimehele vajaliku looma tapmist.

Pärast nõukogude võimu kehtestamist muutusid šamaanid [---] Nõukogude administratsiooni tugevateks vastasteks [---]. On ilmne, et ei šamaanid ega teised ekspluataatorid ei saanud kella tagasi keerata ja nende mõju jäi lühiajaliseks (Levin \& Potapov 1964: 10).

Need read pärinevad etnoloogidelt, kes küll tegelikku olukorda tundsid, aga olid selleks, et üldse oma töid avaldada, sunnitud kasutama selgelt ideoloogilisi väiteid ühes etnograafiliste kirjeldustega, milles räägiti enamasti minevikuvormis. Selline esitusviis jättis varju Siberi rahvaste traditsiooniliste kultuuride tegeliku olukorra. Hilisemad, pärast Nõukogude Liidu lagunemist avaldatud Vene ja teis-

http://haldjas.folklore.eeltagused/nr26/ohverdus.pdf 
Olga Balalajeva, Andrew Wiget

te maade teadlaste artiklid kirjeldavad olukorda palju mitmekülgsemalt (Golovnjov 1995; Pika 1999; Balzer 1999).

Märtsis 1992 osalesid käesoleva kirjutise autorid rahvusvahelisel ekspeditsioonil Lääne-Siberis, et valmistuda järgnevateks aastateks kavandatud põhjalikumateks välitöödeks hantide asualal, samuti selleks, et määrata esialgsed maksud idahantide asualal arendatavale naftatööstusele. Ekspeditsiooni juht oli Olga Balalajeva, kes võttis eeltöödel aluseks neli varasemat välitööd samas piirkonnas. Tänu Russkinskije asulast pärit handist võõrustajale sõidutati meid helikopteriga põdrakarja juurde Trom-Agani ülemjooksu lähedal, mis on idahantide asuala põhjatipp. Sinna kogunes mitmeid peresid, rahvast lisandus ka meie kohalejõudmise päeva pärastlõunal. Peagi selgus, et algamas oli põdra ühisohverdamine (handi k myr), et tervitada järgmist päeva pühas hiies, mis asus $6 \mathrm{~km}$ kaugusel kogunemiskohast. Ka meid kutsuti osalema. Ometi kahandasid asjaolud, mis tegid meid erakorralise sündmuse privilegeeritud tunnistajateks, informatsiooni hulka, mida oleksime võinud saada otse võõrustajalt. Oleme käinud idahandi asualal välitöödel igal suvel alates 1994. aastast. Käesolevas artiklis kasutame informatsiooni, mis pärineb idahandi põdraohverduse keskkonda kirjeldavatest ja interpreteerivatest intervjuudest.

Artikli esimeses osas anname detailse ülevaate 1992. aasta märtsis korraldatud põdra ühisohverduse struktuurist. Artikli teine osa näitab, kuidas myri struktuur on vastavuses handi ususüsteemiga, mille ülesandeks on tagada toit ja majanduslik heaolu. Kolmandas osas püüame interpreteerida ohvrirituaali erijooni, et illustreerida handi usupraktika kohanduvat olemust, eriti kultusspetsialistide tegevuses ja nende rolli määratlemisel. Järeldame, et vaatamata paiguti rohkem või vähem poolehoidjaid leidnud vene õigeusu kiriku mõjule ja rahvusliku usundi allasurumisele nõukogude võimu aastatel ning hoolimata naftamaardlate kasutuselevõtuga seotud survest on handi uskumused ja rituaalid täiesti elujõulised, kuigi kohandatud tänapäeva tingimustele.

\section{Ajalooline ja etnograafiline taust}

\section{Hantide juures}

Handid (vanemas, nõukogude-eelses kirjanduses ostjakid) on soomeugri keelt kõnelev rahvas, keda arvatakse olevat umbes 22 000, 
üks arvukamaid 45-st Põhja-Venemaal hajali elavast põlisrahvast. ${ }^{2}$ Arheoloogilised väljakaevamised näitavad, et nad on asustanud Lääne-Siberit vähemalt 3000 aastat, võib-olla kauemgi. Keelelised andmed räägivad, et nende praegune asuala on olnud osa protouurali rahvaste kodumaast, mis ei puuduta ainult nendega sarnase eluviisiga rahvaid, nagu mansid ja neenetsid, vaid ka soomlasi ja ungarlasi (Kossarev 1984; Tšemjakin \& Karatšarov 1999). Vastavalt 1989. aasta rahvaloendusele elab Handi-Mansi autonoomses ringkonnas ligikaudu 31000 obiugrilast, kellest 8641 on mansid ja 22521 handid. Maa-ala on subarktiline, boreaalsete metsade ja soodega ning asub 25-100 meetri kõrgusel merepinnast. Handid jagunevad kolme rühma: põhja-, lõuna- ja idahandid. Neid eristavad dialekt, elatusviis ja materiaalne kultuur. Põhjahandid elavad Belojarski ja Salehardi piirkonnas. Lõunahandid assimileeriti vene ühiskonda 20. sajandi keskel. Idahandid asustavad Obi jõe keskjooksu ja lisajõgede ümbrust.

Arheoloogiliste andmete järgi on handid elanud vähemalt 17. sajandi algusest saadik hõredalt laial maa-alal perekonnaasundustes, kus nad jätkavad tavakohast jahimeheelu. Paljud neist oskavad lugeda ja kirjutada vene keeles, mõned on kakskeelsed, kuid eelistavad rääkida handi keelt. Kogu handi kodumajandusel on tugev jahinduslik ja kalastuslik taust, kuid sellel on siiski olulisi regionaalseid erinevusi. Põhjas, Obi alamjooksul ja Obi keskjooksust põhja pool (Ljamini, Pimi ja Trom-Agani jõe ääres) on üheks elatusvahendite hankimise osaks põdrakasvatus, lõunas, Irtõši ümbruses põllundus ning Obi keskjooksust lõuna pool on säilinud üksnes jahindusel ja kalandusel põhinev elatusviis (Wiget 1999a). Handi ühiskonna struktuur põhineb laiendatud perekondadel (suurperedel) ehk isapoolsel sugulusel. Suguluses olevad perekonnad moodustavad hõi$\mathrm{mu}$ (handi k sir). Praegune asundusmudel on mõjutatud migratsioonist ja sunnitud ümberasumistest Obi keskjooksu piirkonnas (Martõnova 1998). Mitmed handi hõimud nõuavad mõnede Obi lisajõgede traditsioonilist kasutamisõigust. Osaliselt sellepärast, et nad usuvad oma suguvõsa pärinevat jumalikest esivanematest, kes on vastutavad jõgikondade loomise eest, mille alal enamik hõime elab. Suurem osa handi suurperesid elab oma põlisel jahiterritooriumil, mida kaitsevad perekonna jumalad, keda peetakse loojate-jumalate järeltulijaiks. Seega usuvad handid, et püha võim on ajalooliselt pandud nii maastikku kui ka sugupuusse (Balalajeva 1999). 


\section{Olga Balalajeva, Andrew Wiget}

Lääne-Siber on maailma kõige suuremate naftavarudega. Tõsised naftaotsingud algasid 1960. aastate lõpul, kui avastati esimesed leiukohad. Sel ajal elas Surgutis vähem kui 10000 inimest (Surgut sai linnaõigused alles 1968. aastal). 1970. aastatel domineerisid geoloogilised tööd piirkonna lääneosas, Surguti ja Hantõ-Mansiiski vahel, samal ajal kui pool idaosast (Surgutist Nižnevartovskini) andis juba esimese arvestatava naftatoodangu. 1980. aastate lõpuks oli peaaegu kogu piirkond, välja arvatud mõned üksikalad (Kazõmi ja Suur-Jugani jõgikond), energeetikaministeeriumi ja valitsuse naftamonopoli valduses, et arendada naftapuurimist ja -töötlemist. Tegelikkuses toetas see piirkond tõhusalt kokkuvarisevat Nõukogude majandust, tootes odavat kodumaist musta kulda ja teenides naftaekspordist dollareid. Seda aega iseloomustas handi perekondade sunnitud ümberasustamine perekonna traditsioonilistelt jahialadelt, samuti sealsete loodusvarade hävitamine. Tuhandete aastate pikkusest asustusest on tänapäevaks järele jäänud vaid mõned kalandusest ja jahindusest elatuvad perekonnad Vahhi, Agani, Salõmi ja Vasjugani jõe ääres, kuigi veel kolmkümmend aastat tagasi olid kõik sealsed alad tihedalt asustatud ja seal oli säilinud rikkalikult põliseid elukorraldusvorme. Teised jõgikonnad, nagu Pimi ja Trom-Agani ümbrus, on saanud tugevaid välismõjusid ja handid elavad seal hõredalt. Ainult Ljamini ja Jugani jõgikonnas on handi perekonnad kannatanud minimaalset kahju (Wiget \& Balalaeva 1997, 1999; Wiget 1999b).

Handid usuvad kolmemõõtmelisse maailma, kus keskmine maailm asub ülemise - taeva - ja allmaailma vahel. Iga maailm on jaotatud seitsmeks tasandiks. Taevajumala Numi-Torumiga ei saa otseühendust, vaid tuleb pöörduda ühe või mitme poole tema seitsmest pojast ja seitsmest tütrest, kellest igaüks on mõne loodusmaailma osa (nagu jõed, kalad, loomad) kaitsja. Tema inimese kehastuses noorima poja tõstsid vennad vanema seisundisse, kusjuures loomana kehastas see noorim poeg metsade valitsejat karu. Nagu paljudel põhjarahvastel tavaks, peetakse ka siin tapetud karu auks karupeieid (Schmidt 1985).

Handi usk ja usuline praktika pole tänapäevastest muutustest puutumata. Üks Pimi jõgikonna hant jutustas meile, kuidas praegused asjaolud on mõjutanud ühisohverduse käiku:

Suur-Pimi jõel oli łun [vaim nimega] Pawt-iki. Keegi ei tea, kus ta praegu on. Seal oli koht, kuhu koguneti myri puhul 
rohkem kui kolmkümmend aastat. Seal oli üks saar. Kui naftaotsijad tulid ja sinna puurtorni püstitasid, läks hun sealt ära. Keegi ei käi enam selles paigas. Enne seda ei läinud inimesed sinna, sest nad kartsid surveavaldusi. Noored ei läinud, sest nad ei mõelnud huide peale.

Vaatamata repressioonidele, pühapaikade hävitamisele ja akulturisatsiooni survele jätkuvad hantide loomaohverdused. Isikliku põdra avalik ohverdamine handi perekonnapea heakskiidul on mõningatel "ametlikel" puhkudel isegi kohalike või rahvusringkonna omavalitsusametnike silmis vastastikuse hea tahte ja handi kultuuri elujõu märk. Poolametlikud põdraohverdamised tõstatavad hulgaliselt küsimusi, mida käesolevas töös arutada ei jõua (vt Leete 1997, 1999). Sellised poolametlikud rituaalid erinevad siiski ühisohverdustest, mida kogukond korraldab vaid piiratud osavõtjatele - kogukonnale endale. Just sellist põdraohverdust õnnestus ka meil pealt näha.

Kui kellelgi tekib tänapäeval küsimus, miks inimesed ikka veel ohvreid toovad, võime anda väga üldiseid vastuseid. Pimi jõgikonna hant ja šamaani poeg K.K. täheldas, et nemad [łunid] muudavad inimese elu lihtsamaks, elu pikeneb, nad saavad aidata inimestel paraneda [haigustest], sest nad teavad, et inimene toob nendele iiri. Tema lähim naaber on šamaan, kes on juhtinud kahte myri, ja viimase kolme aasta sees on K.K. ka ise korraldanud ühe myri. SuurJugani jõgikonna hantide vanem P.K., kelle tiitliteks on mantje-ku ja arehta-ku (juttude ja laulude tundja), kinnitas samuti, et inimesed paluvad õnne ja majanduslikku heaolu. ${ }^{3}$

\section{Ajalooline ülevaade handi põdraohverdusest}

Põdraohverdust peeti handi usundipraktika erijooneks juba 16. sajandil (Karjalainen 1995: II 98). Kõige varasematest ülestähendustest on selgunud, et handi põdraohverdus on osa suuremast usundikompleksist, mis seostub mitmete loomade tapmisega, kuid see on karukultusest erinev traditsioon. Ajaloolised ja struktuurilised suhted nende kahe traditsiooni vahel aga jäävad käesolevast käsitlusest välja. ${ }^{4}$

Kustaa Fredrik Karjalaise välitööde tulemused avaldati 1920. aastatel, need olid dateeritud eelmise sajandivahetuse aastatega (18991904), seega hantide nõukogude ateismikampaaniale ja kollek- 


\section{Olga Balalajeva, Andrew Wiget}

tiviseerimisele allutamise eelse ajaga. Tema uurimuse kohaselt on hantidel kaht liiki loomohverdusi: veriseid ja veretuid (Karjalainen 1995: II 107). Meie välitööd kinnitavad, et handid kasutavad siiani handikeelseid termineid, et teha vahet kahel põhimõtteliselt erineval ohvrirituaali liigil, mis päädivad söömaajaga. Iir tähendab vereohvrit, mille puhul tapetud looma veri kogutakse kokku ja juuakse ära ning mõnda osa ohvrilooma lihast süüakse toorelt. Pori on veretu ohvri handikeelne nimetus. Sel juhul keedetakse ohvrilooma liha enne söömist.

Vereohvreid võib teha individuaalselt või kollektiivselt. Iiri võib individuaalselt läbi viia lapse sünni puhul (Karjalainen 1995: I 59) ja mõne inimese matustel (Karjalainen 1995: II 93). Kui perekond peab mõne kriisiolukorra tõttu, nagu haigus, vajalikuks korraldada iir, ent see pole võimalik, võivad nad ka lubada, et toovad ohvri kunagi hiljem (Karjalainen 1995: II 120). Ohvrirituaali edasilükkamine ei ole aga võimalik ühisohverduste puhul, millel on enamvähem kindel kuupäev ja kuhu kogunevad perekonnad kogu piirkonnast. Idahandid nimetavat kollektiivset iiri myriks. 19. sajandil jaotas Nikolai Gondatti ohvrirituaalid korrapärasteks ja juhuslikeks: ohverdamine võib olla ajastatud kas juhuslikult või mingi korrapära alusel. Juhuslikud ohverdused sõltusid olukorrast ja paganate entusiasmist. Korrapärased ohverdused on kohustuslikud ja need korraldatakse tavaliselt kevadel enne kalastamishooaega ja varasügisel, kui kalastamishooaeg on lõppenud, hilissügisel enne talvist jahihooaega, seejärel pärast jahihooaja lõppu ja muudel analoogsetel juhtudel (Gondatti 1888b: 10).

Kui Kustaa F. Karjalainen (1995: II 120) märgib, et kollektiivseid ohverdusi viidi minevikus läbi (nakkus)haiguste puhul, siis tänapäeval seostuvad need enamasti N. Gondatti kirjeldatud aastaajast sõltuva elatusvahendite hankimise mudeli muutumisega. ${ }^{5}$

Sellest ajast on teada, et handid ohverdasid ka teisi loomi peale põtrade, näiteks hobuseid, lehmi, pulle, oinaid ja isegi kukkesid (Karjalainen 1995: II 101). Iirina eelistati ohverdada siiski põtru ja hobuseid. ${ }^{6}$ Hobune oli põdra järel kõige väärtuslikum ohver, temaga võis asendada isegi põtra (kuigi 1995. aastal väitis üks Pimi jõgikonna hant, et põtra saab asendada seitsme pudeli viinaga). 1998. aastal pidasid Suur-Jugani jõgikonna handid plaani koguda raha hobuse ohverdamiseks. 
Vaidlused igasuguste loomohvrite kohasuse üle viivad kiiresti väitluseni loomohvri toomise funktsioonist ja struktuurist. K. F. Karjalainen väitis, et

[---] loomohver tähendab peaasjalikult kasuliku looma ohverdamist. On loomulik, et kodustamata elukad, metsloomad ega -linnud ei saanud hantidel kuidagi olla ohvriloomad samas mõttes nagu põder, isegi kui neid mõnikord mõne vaimu heaks tapeti (Karjalainen 1995: II 103).

Näiteks võidi põder ohverdada ka lahkunute transportimiseks (Karjalainen 1995: I 95). Kasulikkuse all võib mõista ka muud kui sobivust transpordivahendiks. K. F. Karjalainen spekuleeris, et vaimule peab ka süüa pakkuma. Selles asjas oli liha ugrilastele oluline ja seetõttu omandas loomohver kergesti toiduohvri iseloomu või sarnanes (surnute või vaimude) söötmisega. Mõlemad eesmärgid kehtivad ka tänapäevaste ohverdamiste puhul - ohvripeied on nüüd isegi veel harjumuslikumad ja olulisemad (Karjalainen 1995: II 103).

Toiduse saamine sõltub ulukite ja kalade, sh põtrade tapmisest, kuid toiduse hankimine iseenesest ei saa olla seletuseks kodu- ja metsloomade ohverdamise erinevusele. Erinevus, mida tähistavad kaks rituaalset tapmist kirjeldavat handi sõna iir ja pori, näib põhinevat sellel, kas looma tapmise eesmärk on toiduse hankimine või on toit vaid ohverdamise kõrvalsaadus. K. F. Karjalainen mainib ka ohverdamisrituaali toidu hulka ja söömingu ulatust, et eristada loomade ohverdamist "asjade ohverdamisest" - selle liigituse alla kuulub nende loomade nahkade ohverdamine, keda ei jahita toidu saamiseks, vaid kasuka muretsemiseks (Karjalainen 1995: II 103).

\section{Myr - idahandi kollektiivne põdraohverdus Myri korraldamine}

Myri läbiviimine võib olla komplitseeritud. Meie artikkel kinnitab N. Gondatti uurimust (1888b) vereohvri (iiri) kohta, mis on jäänud tänapäevani muutumatuks: iir korraldatakse erandlike asjaolude puhul või seoses aastaaegadega. Välitööde põhjal teame, et individuaalse iiri viivad läbi üksikisikud jahihooaja alguses ja juhul, kui kaua eemal viibinud pereliige naaseb koju, näiteks, kui ta on olnud haiglas või internaatkoolis. Sama paistab kehtivat ka kollektiivse 
Olga Balalajeva, Andrew Wiget

iiri puhul. K.K. jutustas, mis juhtus hiljuti naaberperedes Ai-Pimi jõe ääres:

Esimese [hiljutistest] myridest viis läbi Z.N. Teda külastas keegi [vaim]. See andis talle korralduse kutsuda kokku inimesed kolme myri jaoks. Ta kutsus neid kokku kaks korda, kolmandat korda enam mitte. Siis juhtus midagi minu peaga ja nad [vaimud] kargasid mulle kallale. Nii korraldasin mina kolmanda.

Ohverdamine, milles osalesime, leidis aset hiliskevadel. See oli aastaajaga seotud kollektiivne ohverdus talve lõpu tähistamiseks enne perede kolimist suvemajadesse. Handid, kes ei võta osa kollektiivsest myrist, võivad korraldada iiri oma jahiterritooriumil enne aastaajast johtuvat muutust jahindus-, kalandus- ja põdrakarjatamispaikades. Kui myri korraldamise otsus on langetatud, peab selle aja ja koha teatama kõigile osalevatele peredele. Aega teatatakse selliselt, et igasse majapidamisse saadetakse pulgake nii paljude täketega, kui palju päevi on jäänud kogunemiseni. Oleme kuulnud, et teatamiseks saadetakse ka sõlmedega niit või nöör, millel peab iga päev kuni kogunemiseni ühe sõlme lahti harutama. Täksitud pulgakesi peavad kohale viima ohverdusest osavõtjad. Kutsed viiakse laiali mõne kohaliku peremehe juurest, kes ei pea olema kultustegelane.

Kohavalik sõltub sageli sellest, mis tširta-kule (handi kultustegelane, vt allpool) unes ilmutatakse, või inimesest, keda on saadetud myri otsima. Tavaliselt on nendel kohtadel mütoloogiline tähendus. Nagu K.K. eelnevalt märkis, on viimasel ajal naftapuurimise tõttu lõhutud paljud paigad, kus myri on korraldatud. Neid kohti peetakse aga endiselt pühadeks, kuigi need pole rituaalide läbiviimiseks enam kõlblikud. Näib, et lõhutud koha tähendust on võimalik üle kanda teisele paigale. Nii oli ka kõnealuse ohverdamise puhul. 1994. aastal rääkis J.S., et myri korraldamiseks ettenähtud pühapaika kutsuti Kõrge Nulu Ase selle koha järgi, mis asus kaugemal allavoolu, aga lõhuti tee-ehituse käigus. Uue ja vana koha suhe on ebaselge, ka ei tea me, mis ulatuses ja kui sageli sellist nähtust esineb, küll aga teame, et see pole ainujuhus. 
Olga Balalajeva, Andrew Wiget

\section{Esimene päev: palve ja laul}

\section{Rituaalieelne sotsiaalne tegevus}

Meie helikopter jõudis kohale hilisel pärastlõunal. Võõrustaja tutvustas meid vanemale A.M-ile, kes ütles, et kokkutulnud valmistuvad põdra ohverdamiseks järgmisel päeval ja ka meie oleme teretulnud. See oli esimene päev, kui kavandatavast ohverdamisest kuulsime.

Meie laager koosnes kolmest suurest telgist (vn tšum). Nende ees oli pool tosinat kelku ja kaks saani, millel istusid naised ja ajasid juttu. Mõned neist mängisid sealsamas kõrval väikeste lastega. Teised uurisid juhuslikult mööduvaid noormehi - nende seas olid naiste abikaasad. Mehed olid seotud millegagi, mis tundus meile "handi olümpiamängudena”. Järgneva pooltunni jälgisime noorte meeste võistlust tugevus- ja kiirusaladel: püstises asendis järjest kõrgemale tõstetavast nöörist ülehüppamine, üha suurendatavast põdrajäänuste hunnikust ülehüppamine ja põdranahast punutud lasso viskamine üle neljameetrise teiba, mida handid kasutavad põdra juhtimiseks.

Pärast seda, kui olime oma toidu valmis teinud ja ära söönud ning väljas oli pimedaks läinud, algas trummilöömine ja laul peremehe telgis. See kestis peaaegu hommikuni. Et olime sattunud rituaalsesse konteksti üsna ootamatult ja meil polnud mingeid eelteadmisi idahandi etiketist, ootasime peremehe küllakutset, kuid järgmisel hommikul selgus, et tema eeldas meie initsiatiivi.

\section{Kärbseseenešamanism ja łu łide palumine}

Trummilöömine ja laulmine olid osa järgmiseks päevaks kavandatud ohverdamise ettevalmistavast riitusest. 1990. aastast kolm korda myril osalenud K.K. jutu järgi korraldatakse kärbseseene (Amanita muscaria, vene k muhhomor) toimel esile kutsutavad selgeltnägemisrituaalid tavade kohaselt nii enne kui ka pärast ohverdust. Neid viib läbi tširta-ku, idahandi kultustegelane, kelle peamiseks ülesandeks on laulda trummipõrina saatel vaimulaule. K.K. väitel on ideaalne, kui rituaaliks on varutud seitse suvel korjatud kärbseseent. On vaja katta laud, panna sinna kärbseseened, leib ja toit. Tširta-ku peab ära sööma kõik kärbseseened. K.K. kirjelduse järgi oli sellel ööl korraldatud selgeltnägemisrituaal tüüpiline. Pärast laua katmist, kuid enne sööma hakkamist võivad kohalviibijad esitada küsimusi. 


\section{Olga Balalajeva, Andrew Wiget}

Üks tavalisi küsimusi on: "Mida teha, kui põdrad või inimesed jäävad haigeks või ei ole kala- ega jahiõnne?" Muud küsimused võivad käia kogukonna ja selle probleemide lahendamise kohta. Kui myr korraldatakse uues paigas esimest korda, on peamine küsimus see, kus on õige koht põdra ohverdamiseks. Kui vana koht on rikutud, ootavad inimesed, et nad juhatataks teise kohta, kust rõiva- ja nahaohvrid ning ohverdamine tee peale ei paista. K.K. lisas ka, et selgeltnägemisrituaal on seda parem, mida väiksemaid kärbseseeni kasutatakse. Vanu seeni ei tohi üldse korjata, sest "vanad valetavad".

Siis sööb tširta-ku ära kõik kärbseseened. K.K. ütles, et kui kohal on mõni veel kangem šamaan, kes küll kärbseseeni ei söö, võib juhtuda, et seene mõju kandub tširta-kult üle sellele kangemale šamaanile. Ta rääkis, et viimase, tema korraldatud myri ajal sõi tširta-ku ära kõik kolm korjatud kärbseseent ja siis jäädi ootama, kas need ka kellelegi teisele mõjuma hakkavad. Mõju kandus üle mitmele inimesele, kes kõik läksid näost punaseks, aga kõik "keeldusid sellest". Leidus vaid üks vana mees, kes trummeldas sõrmedega vastu pead ja hakkas laulma, kui talle trumm anti.

Igal tširta-kul on oma kärbseseenelaul. Need laulud (handi $\mathrm{k}$ papx areg) on rütmiliselt struktuurilt sarnased handi joomalauludega (handi werem areg). Nende ülesehitust peetakse spontaanseks. K.K. järgi on iga kärbseseene puhul laul erinev, sest iga kärbseseen annab laulule omad sõnad. Kärbseseen ise teab. Nad on nagu łuฤ. Laulu ajal kuuleb šamaan vastuseid küsimustele. Ta võib ka öelda, kellel on hästi läinud, ja paluda neilt vereohvrit (iiri).

\section{Teine päev: ohverdamine}

Ärkasime kõik kell kuus hommikul põdrakarja liikumise peale see oli öösel metsas olnud. Loomad liikusid telkide vahel ja kaapisid lund. Kella kümne paiku pärast hommikusööki lahkus kogu mitmest suurperest koosnev seltskond laagrist ja nartade rivi hakkas liikuma pühapaika.

Meid juhtisid põhjapõdrad ja mootorsaanid. Osalejaid oli umbes 60 inimest: 25 meest, 21 naist ja 12 last ning seitse külalist (kolm ameeriklast, üks britt ja kolm venelast). Üks vanematest ütles, et see on esimene kord, kui ohverdusrituaalil osalevad inimesed väljastpoolt kogukonda, kuigi üks erandlik ohverdus olla olnud ka 12 aastat varem - siis võttis rituaalist osa hantide seas üleskasvanud venelane. 


\section{Kogunemine ja ohvripaiga ettevalmistamine}

Kogunemine ja naiste-laste eraldamine. Naised jäeti jääkaane all oleva Trom-Agani jõe käänus seniks nartadega läänekaldale, kuni mehed ohvripaika ette valmistasid. Naised ei tohtinud söögitegemise alalt eemalduda. Keeld naistel jahirituaalis osaleda on hantide, nagu paljude teistegi küttimisest ja korilusest elatuvate rahvaste seas tavaline (Karjalainen 1995: II 120; Kulemzin 1976: 35; 1984: 95).

Koha ettevalmistamine. Koht paiknes kahel teljel. Üks telg kulges mööda jõge kahe tegevusvälja - puust ohvrialtari ja lõkke vahel. Sellel teljel pandi jääd katva lume sisse eraldusmärgiks noor kasevõsu. Pole teada, kas see on kohustuslik element. K.K. ütles, et tema korraldatud myril Pimi jõel kaske püsti ei pandud ja ta pidas seda paikkondlikuks eripäraks, sest igal jõel tehakse seda isemoodi. Selle võsu juurde kaeti altarilaud, et varustada Torumi asjadega ja kutsuda teda rituaalis osalema. Selle juurde kogunesid jahimehed kodustatud põhjapõtradega, keda nad kasutavad veoloomadena.

Altari vastas asus teine tegevusväli, kuhu oli tule tegemiseks lumme sügav auk kaevatud; naised ja lapsed ei tohtinud sealt üle astuda. Teine telg kulges üle esimese kaugelt kalda pealt risti üle jõe puust altari poolsele kaldale ja metsa. Metsas lõppes telg sellel kohal, mis oli ette nähtud metsavaimudele ja Torumile ohvrite toomiseks.

\section{Uue lõkke süütamine}

Kui mehed olid lõpetamas koha üldist ettevalmistamist, läksid mitmed neist selle keskele asetatud puuhalu juurde. Puuhalule tehti suur ruudukujuline täke. Vaatamata usinusele ei saanud mehed ikkagi tuld läidetud. Lõpuks hoidis keegi puutikku päris tulemasina pöörleva otsa juures selle kokkupuutehetkel süütisega ja nii saadi tuli põlema.

Kuigi tikkude kasutamine tule süütamiseks osutus keelust hoolimata vajalikuks, on selline keeld midagi enamat kui vanadest tavadest kinnipidamine. Vanem uue lõkke süütamise viis kinnitab uskumust, et tuli on asjade elav vaim, kes tekib või tuleb nähtavale tulemasinast selgelt tajutava iseenesliku süttimise abil. 
Olga Balalajeva, Andrew Wiget

\section{Must mees}

Kui uus lõke oli süüdatud, kaevasid teised mehed lumme suure tuleaseme, tõid sinna tule, ühe suure ja palju väikesi katlaid. Naised seisid vaikselt või istusid edasi nartadel, ajasid juttu, klatšisid, kantseldasid lapsi ega pööranud võib-olla sihilikult meeste tegevusele erilist tähelepanu. Samal ajal olid mehed ametis plekktrumlile antropomorfse kuju andmisega. Seda kuju nimetasime me Mustaks Tõvemeheks. Kuju pandi seisma jõe läänekaldale, kusjuures vastaskaldal oli teine samasugune, juba varem valminud kuju.

\section{Altariohvrid}

Altarile asetati rõivaid, lihakonserve ja raha. Neid uuriti põhjalikult ja arutleti nende väärtuse üle. Mõned rõivad põlati ära, aga meile jäi ebaselgeks, mis valiku alusel. Ehkki rõivastel, nagu allpool juttu tuleb, on värvist ja kangast sõltuv sümboolne väärtus, lubati tavaliselt altarile tuua punase-valge- või musta-valgeruudulisi rõivaid.

Konservtoidud olid küll lubatud, kuid ühe meie seltskonda kuulunud inimese toodud mereandide konservi ei söönud kogu peo ajal mitte keegi. Kas isiklike eelistuste pärast või seetõttu, et konkreetselt selle rituaali ajal oli kalasöömine keelatud, jäi selgusetuks.

\section{Ohverdamine}

\section{Pühitsemine ja palved}

Selleks ajaks oli peaaegu keset jõge asuva altari taha ohverdamispaika toodud nartade vahelt üksteist ohverdatavat põtra. Iga perekond oli andnud ohvriks ühe looma. Põdrad olid pandud meeste ette, kes seisid ebakorrapärases rivis näoga lõunasse, päikese poole. Kell oli umbes 11 enne lounat.

Mees, kes oli juhtinud altarile toodavate asjade ülevaatust, astus edasi ja hakkas kaebliku lauluga juhatama meeste palvet Torumile ja Kon-ikile. Aeg-ajalt katkestasid nad oma palveid hüüdega: Wowo-wo! Palvete ajal kummardasid kõik mehed vähemalt kaks tosinat korda päikese poole, siis pööras igaüks end korra päripäeva ümber. Tsükkel kordus veel kaks korda, et oleks täidetud tegevuse kolmekordsuse nõue. Kolmanda ümberpööramise lõpul laskusid kõik ühele põlvele ja puudutasid otsmikuga lund. 
Arvatavasti on kummardamine ja põlvitamine õigeusu rituaalide mõju; põlvitamine on tõenäoliselt handi täpne vaste õigeusu zemnoi poklonile ehk maani kummardusele. Naised jälgisid tegevust oma kohalt teisel pool lõket, olles seega pisut eemal. Kui tuli kutse palvele, kogunesid nad ebakorrapärastesse rividesse, vanemad naised ees, ja osalesid enam-vähem samal viisil nagu mehed.

\section{Lasso heitmine}

Pärast palveid Torumile ja Kon-ikile, mida juhatab multe-ku (handi kultustegelane, kelle ülesandeks on rituaale juhtida), püüavad mitmed nooremad mehed heita lassot üle jõeäärsete puuvõrsete. Handi põdrakasvatajad kasutavad põtrade püüdmiseks põdranahast punutud lassosid (handi k arkan), kui nad tahavad looma kelgu ette rakendada. See on oskus, mida nad üksteise võidu lõbu pärast harjutavad, püüdes heita lassot üle pikkade teivaste, millega põtru juhitakse.

Meile räägiti, et lasso heitmine toovat õnne ka tegelikul põdrapüüdmisel.

\section{Ohverdamine ja ohvriloomade surmamine}

Ohverdati üksteist põhjapõtra. Kümnel neist oli kaelas valge või valge-punasekirju, ühel must riideriba. Põhjapõdrad ohverdati kiiresti ja puhtalt. Üks mees lähenes põdrale paremalt eest, vasak käsi õrnalt põhjapõdra koonu peal, parem hoidmas kinni tema kaelas olevast kangatükist. Teine mees lähenes loomale tagant paremalt ja lõi ta üheainsa kirvepärahoobiga lagipähe sarvede vahele uimaseks. Loom kukkus raskelt ning kolmas surmas ta pika ja peenikese noaga üheainsa täpse torkega südamesse.

Põhjapõtradele kaela seotud riidetükkide värvidel on vana ja sügav tähendus. Valge seostub taevase maailma, must allilma ja punane maapealsega. K. F. Karjalainen on teinud mõned üldised tähelepanekud ohvriloomade olulisemate tunnuste kohta: looma sugu peab olema sama kui sellel vaimul, kellele ta ohverdatakse; värv oli tähtis ohvriloomade identifitseerimisel; tavaliselt ohverdati kolm või seitse looma (Karjalainen 1995: I 97-98).

P.K. tähelepanekute järgi Juganil inimesed (välja arvatud multeku) arutavad, kui palju põtru nad kellelegi annavad; [---] multe-ku [üksinda] kutsub jumala välja. K.K. kinnitas, et tema kodukandis, 
Olga Balalajeva, Andrew Wiget

Obi põhjaosas mä̈̈rab multe-ku, kui palju põtru kellelegi [millisele hupjle] ohverdada.

K.K. kirjeldas ka mõningaid põtrade ohverdamise üksikasju nende kolme myri ajal, millel ta hiljuti osales ja millest ühel ta peremeheks oli. Tema meelest on ohvrite järjestuses korrapära.

Multe- $k u$ määrab ohvripõtrade arvu ja saaja. Kui ohvriloomi on palju, siis määratakse igaühele kolm. Kui neid on vähe, siis ühele $i k i l e\left[h_{\eta}\right]$ kaks ja teistele igaühele üks. Kui juhtub olema valgeid põdrapulle, tuleks need ohverdada esimesele kahele.

Järjestus on selline: esimene põder läheb Vanaisale (Torum, $\mathrm{Nu}$ ming-iki), teine Kon-ikile, kolmas Tšornõ-ikile (Must Tõvemees Puixt-iki, Kul-kył hu ), neljas Muix-imile (Muix a $\eta k \mathrm{i}$ ), viies Tiłsile (Kuu) ja Kotetile (Päike), kuues Kazõm-imile, seitsmes Woi Ort$i k i l e$ - kalade, loomade ja lindude jagajale ja kaitsjale (üks Kon-iki vendadest), kaheksas Agani, Trom-Agani, Pimi ja Ljamini jõe vaimudele (nendele neljale hu rjle võib igaüks oma põdra ka eraldi tuua kui keegi tahab ohverdada Aganile, siis ta seda teeb, või Pimile või mõlemale; siin on palju võimalusi) ja üheksas Pupit-Konile (Suur Karu, samuti Kon-iki vend).

Pärast selle järjestuse andmist tegi K.K. tähelepaneku, et

Nom-imile ohverdatakse põder pärast seda, kui ohvrid on toodud esimesele kolmele või neljale meesjumalale. Tema on nende ema, Vanaisa naine.

See tähendab, et talle tuuakse ohver samal kohal, kus kõigepealt Muix-imile (Muix-alkile).

Pärast ohvriloomade tapmist hakkasid meestepaarid nahka nülgima, kaasa arvatud peade ümbert, ja seejärel lihakehasid tükeldama. Jälgiti hoolega, et veri ei voolaks lumele. Peanahk nüliti eriti hoolikalt, alalõug eemaldati ja lõigati ära. Reieluud ja ülemised kintsulihased eemaldati ja lõigati samuti ülejäänud lihakeha küljest lahti. Tegutseti paaristikku, kiiresti ja oskuslikult, nii et see töö ei võtnud rohkem aega kui kümme minutit looma kohta. Seega olid loomad kahekümne minutiga ohverdatud.

Loomade tükeldamisel leiti, et kaks neist olid tiined. Looted maeti hiljem hoolikalt jõe peale lumme. K.K. jutu järgi usuvad handid, et see on eriti väärtuslik ohver:

Kui tapetakse emane põder, kelle sees on loode, arvatakse seda kahe põdra ette. 
Olga Balalajeva, Andrew Wiget

\section{Kase ja Musta Tõvemehe toitmine}

Lihalõikamise ajal kleepus väikseid lihatompe kaseokste külge. Need olid lõigatud spetsiaalselt selliseks ohvriks ja pandi altari juurde lumme. Tavakohaselt visati liha- ja veretombud Musta Tõvemehe plekk-kuju pihta. Trom-Agani jõgikonna hant B.N. ütles 1994. aastal, et Tšornõ-ikil on raudkübar ja plekkrõivad. Küsimusele, mida tähendab lihatompude viskamine plekk-kuju pihta, oskas vastata K.K., kes ütles, et see on haiguste tõrjumiseks.

Nad tegid plekist kuju, sest tal on niisugused [plekk] rõivad ja terava otsaga kübar; see on tema kuju. Visatakse liha, sest alati lõigatakse talle liha ja loetakse palveid; ka kutsuti teda ohverdamisele. Tšornõ-ikist sõltub, kui kaua sa veel elad. Lapsena su tee alles algab, aga tihtipeale jõuavad inimesed siinilmas vaid tee keskele, põhjuseks joomine ja haigused. Kui inimene sünnib, on tal juba tee olemas. Vanasti elasid inimesed vanaks. Tširta-ku aitas neid pisut. Kui Torum enam midagi teha ei saa, siis pöördub tširta-ku Tšornõ-iki poole. Tšornõiki võib näiteks öelda, et selle mehe elu ta enam päästa ei saa.

Oma võimu tõttu on ka Třornõ-iki "kutsutud" ohverdustseremooniale, kuid nagu K.K. ütles, pannakse tema kuju kahjustava võime tõttu ohverduspaigast pisut kaugemale.

\section{Pidustused ja tänuavaldus}

\section{Toiduvalmistamine ja pidustused}

Pärast palveid ja ohverdamist läksid naised tagasi lobisema ja mehed hakkasid tooma nende kätte ohvriloomade osi. Naised said enda kätte sooled ja maod, mida nad pidid puhastama. Suured maod tehti tühjaks ja anti tagasi meestele, et nad need verega täidaksid; väikestesse magudesse pandi puhastatud sooled. Mõned maod aga pandi koos maksade ja südametega katlasse keema. Pidusöök algas leiva ja kuuma teega. Vanem tõi natuke lihatükke, mida söödi toorelt soolaga. Nii mehed kui ka naised sõid osa keedetud maost, südamest ja maksast. Pidustused kestsid terve päeva, kusjuures mehed ja naised kohtusid vaid söögivalmistamislõkke ääres. 
Olga Balalajeva, Andrew Wiget

\section{Altarile ohverdamine}

Pidustuse ajal pandi osa keedetud südametest ja maksadest altarile. Ülejäänud jagati meestele söögiks. Seekord korjati meestelt ka raha ja asetati samuti altarile varem sinna pandud rõivaste ja konservipurkide kõrvale.

\section{Tänuavaldus}

Pidustused lõppesid kutsega uuele palvusele. Mehed ja naised lahknesid ja läksid määratud kohtadesse. Nad moodustasid rivid ja kordasid esimese palve juurde kuuluvaid liigutusi, nagu neid on ülalpool kirjeldatud. Seekord avaldati ohvripalvetega tänu.

\section{Annetuste jagamine}

\section{Tule jagamine}

Pärast tänupalvet kogunes rühm jälle tule ümber, mehed ja naised seisid ettevaatlikult vastaspooltel, kõige lähemal endale määratud alale. Třirta-ku kõndis ringi ja puudutas punase rätikuga kõigi meeste ja naiste otsaesiseid, läks siis üles nartade juurde ja puudutas rätikuga ka sinna jäänud laste ja väikelaste emade otsaesiseid. Seejärel tuli ta tagasi tule äärde, tõstis rätiku üles ja palvetas Tjorasnai a jki poole. Nüüd visati punane rätik tulle. Pärast seda sinna enam puid ei lisatud.

\section{Liha jaotamine}

Naised jäid tule äärde, samal ajal kogunesid mehed, samuti väljastpoolt tulijad kokku ja istusid ringi altari ja söögivalmistamislõkke vahele. Vanem andis kahele noorele poisile korralduse jagada tükeldatud liha meeste vahel. Iga mees sai umbes kolm kilo liha. Poisid küsisid vanemalt nõu, kellele missugune tükk anda. K.K. ütles, et liha jaotatakse selliselt, et keegi ei lahkuks solvatuna. 


\section{Lõpupalve ja naiste lahkumine}

Pärast liha jaotamist meeste vahel moodustasid mehed ja naised uuesti rivid ja kordasid palve juurde kuuluvaid liigutusi, et lõpetada ohverduse formaalne osa, millest võivad osa võtta mõlemast soost inimesed. Kohe pärast seda aga korjasid naised söögitegemisriistad ja söögivarud kokku ning läksid tagasi laste juurde nartadele, saatjaks mõned mehed.

\section{Ohverdusriistade ja ohvriandide paigutamine ning lahkumine}

\section{Altari ja nahkade paigutus}

Mehed viisid altarilauad ja kase metsa. Kohale jäi vaid üks altarile toodud riie. Ohverdatud loomade nahkadele seoti riideohvrid ümber ja viidi need kaldalähedasse metsa. Otsiti välja kaks saledat $15-20$ meetri kõrgust kaske. Üks poiss ronis kordamööda kummagi otsa, kaasas nöör, mille ta viskas üle ühe kõrgemal asuva oksa, lastes seejärel teise otsa maha langeda. Sinna seoti kimp põhjapõdranahku ja riiet ning tiriti kimp üles puulatva. Iga tõmbe ajal itkesid mehed: Wo-wo-wo! K.K. märkis, et need itkud koosnevad ilma tähenduseta hüüetest:

Nad kordavad "Wo-wo-wo", et tõmmata hupide tähelepanu. Mõnikord hü̈̈avad nad kolm, mõnikord seitse korda. Kui viibitakse tundmatus kohas suurel jõel, visatakse münt jõkke ja hü̈̈takse: "Wo-wo-wo!"

B.N. kinnitas sedasama, öeldes:

Need on tõlkimatud hü̈̈ded. Nad saadavad [põhjapõtrade] hingesid üles, et tõmmata endale jumalate tähelepanu.

Kui ohvrid olid ülemise oksa juurde tiritud ja puu otsa roninud poiss need sinna kinni sidunud, ronis poiss alla. Seejärel liikusid mehed päripäeva ühes reas kolm või neli korda ümber ohvripuu. Paljudel teistel ümbruskonna puudel rippusid samuti ohvrid, mis olid sinna seotud varasematel kordadel. Ei tea täpselt, kuhu pandi alalõua-ja reieluud, kuid arvatavasti samuti puu otsa, võib-olla osana ohvrikimbust, võib-olla ka eraldi. 
Olga Balalajeva, Andrew Wiget

\section{Ohvrid männi juures}

Metsa ohvripuude juurde minevast teest veidi eemal on veel üks omamoodi paik. Männi jalamile lumme on pandud kummuli ämber, mille ümber on lahti laotatuna mähitud kaks kangatükki, ilmselt salli. K.K., kes elab ohvripaiga lähedal, mõistis nähtust kui teist liiki ohverdust järgmiselt:

Ämber ja sall. Ämber on maale, Muix-imile - ta on naissoost ja sall on ka temale. Nad palvetavad talle. Nad lõikavad talle ka põtra.

P.K. teadis ka, et

[---] suure iiri puhul pannakse välja pada või ämber, mähitakse see musta salli, kaevatakse isegi mutta, kuid mitte kuigi sügavale, ja jäetakse sinna. See oli naiste ohver naisjumalatele.

\section{Must Tõvemees}

Lõpuks viivad mehed eemale selleks ohverdustseremooniaks valmistatud ja varasema, vastaskaldale asetatud Musta Tõvemehe plekkkuju. Ohvriplats koristatakse ja mehed pöörduvad tšumi ehk laagrisse tagasi.

\section{Õhtune kogunemine}

K.K. teatel kogunevad osalejad pärast ohverdustseremooniat uuesti ja kohtuvad tširta-kuga, kes viis läbi kärbseseenerituaali. Nad küsivad temalt, kas ohverdamine oli edukas ja kas jumalad on põdrad vastu võtnud.

\section{Tseremoonia struktuur ja tähendus}

Kui tänapäeval uurida, mida tahetakse nende ohvritega saavutada, saab isegi teadjamatelt hantidelt kõige üldisema vastuse: õnne ja majanduslikku heaolu, tervist, pikemat ja mugavamat elu. Selle kõrval on kahepoolsuse momenti mainitud vaid kõige üldisemalt, nagu K.K. seda väljendas: vaimud vastavad palvetele, sest nad teavad, et inimesed toovad neile iiri. 
Kui sellised väited viivad mõttele, et majanduslikku heaolu hinnatakse liha, kala ja loomanahkade hulga järgi, tekivad tõlgendamisel raskused. Esiteks, handid kodustavad põhjapõtru, aga põhjapõdrad ei ole nende põhiline toiduallikas. Suurperede põdrakarjade kasinus (umbes 40 looma) lubab Surguti hantidel tappa vaid kaks või kolm põhjapõtra talve jooksul. See tagab 12-liikmelisele suurperele vaid väheldase lihakoguse. Kui majanduslikku heaolu mõõta toidu hulga järgi, saadakse see isegi talvel peamiselt kalastamisest (Wiget 1999a). Kas toiduvarude ohverdamine viib tõepoolest majanduslikule heaolule? Teine keerukus tuleneb asjaolust, et kui enamik hantide toiduvarust saadakse jahil ja kalastamisel, siis ohvriloomadeks on koduloomad. Handid tunnistavad, et see rituaal jõustab inimeste ja vaimude maailma kahepoolse suhte. Kas see tähendab, et tüüpilised ohvrid altaril, nagu rõivad, konservid ja leib, võivad esindada hantide kodustamise teel muudetud metsikust põhjapõdrast anni tagasipöördumist vaimude juurde? Selliseid sõlmpunkte lahti harutades peab arvesse võtma, kuidas kollektiivne ohverdamine jõustub usundis nõutava majandusliku heaolu saavutamiseks, mida ootavad need, kellele rituaalis osalemine tähendab tavadest kinnipidamist.

Ilmneb, et myri funktsioon on esile tuua mitmesuguste jumalate roll keerulises elavate olendite taastootmise eshatoloogias. Seetõttu on rituaalis kolm teemat eriti silmapaistval kohal: sooliste jumaluste osavõtt, nende eriline, kuid üksteist täiendav ühendus taevase ja allmaailmaga ning nende koostöö keha loomisel ja hinge animeerimisel maapealse elu taastootmiseks. Need jõud ilmnevad kõigepealt ohvripaigas, mis paikneb kahel teljel. Esimene, piki jõge jooksev telg ühendab handi mütoloogia duaalsed algelemendid mehed ja Taeva (mille poole pöördutakse kui Päikese poole) naiste ja laste ning Maaga (uue lõkke platsi kohal). Teine, risti jõge paiknev telg ühendab maapealse ilma ohverdamisalal allilmaga, mida tähistavad kaks kuli ehk ky引 huıi - haigustevaimu - plekk-kuju. Siit ilmneb handi kolmemõõtmelise maailma põhiskeem, mis on realiseeritud ohvripaiga ettevalmistamisel. Selle koha piires on kaks põhilist tegutsemisala: kask, altar ja Musta Tõvemehe kuju ning uus lõke ja toiduvalmistamispaik. Selle ruumi ulatuses on kaks jumalat (Tjoras-nai a ๆki ja $k u l$ ) kohal füüsiliste vastete kujul ja teised kaks (Torum ja Kon-iki) kutsutakse kohale palvete abil. Seal läbiviidavate tegevuste rituaalne järgnevus lavastab nende nelja jumala tähen- 
Olga Balalajeva, Andrew Wiget

duste suhteid, kusjuures nende jumalate ühine ülesanne on elusolendite taastootmine.

Ohvripaika korraldavad teljed lõikuvad kase ja altari kohal. Kased, nagu ka need võsud, mida pannakse esimesele, piki jõge jooksvale teljele puust altari ja tule vahel, on handi pühad puud ja nendega seostub sealses mütoloogias palju nähtusi. K. F. Karjalaise järgi on Vasjugani hantidel kujutelm taevasest kaasikust, seepärast seoti kõik päikesele, tuulele ja taevalikele jumalatele mõeldud annid kase otsa (Kulemzin 1984: 166). Kui inimese loomisest võib mitut moodi aru saada, siis vähemalt üks versioon räägib, et inimene on loodud kaseokstest (Kulemzin 1984: 164). Võsu lumme istutamine võib sümboliseerida kõige esimest kaske, mis hakkas kasvama kohas, kus Tjoras-nai a gki, kandes peamise mütoloogilise kultuuriheerose last, taevast maa peale langes. Temast sündisid Numing-iki (Taevamees) ja Muix-a yki (Maanaine). 1994. aastal kirjeldas Trom-Agani hant B.M., kes ei osalenud meiega samal myril, aga kes oli osa võtnud teistest, tuld austavatest myridest, Tjoras-nai a ykit kui veekeerist ookeani keskel, mis pöörleb ümber ookeani põhjas põleva igavese tule. K.K. järgi on Tjoras-nai a lki mänginud inimkonna ajaloos võtmerolli:

Esimeses maailmas elasid hu yid, mitte inimesed nagu meie. Maailma saadeti ringi käima suur tuli, mis selle hävitas. [Vastuseks meie küsimusele ta lisas: Tuli saadeti laiali inimeste uuendamiseks.] Kes ära jooksid, need hukkusid, aga mõned neist, kes ei jooksnud, jäid elama. Tuli oli sü̈̈datud veetulva abil, võib-olla oli ka see tolle naise saadetud, sest tulest sai veeuputus. Mõned lapsed pandi parve peale ja nad ujusid laiali maailma eri osadesse. Nii asustatigi maailm. ${ }^{7}$

Iga tuli on Tjoras-nai a yki tütar (Kulemzin 1976: 45). Need tuled on elusolendid ja neid on võimalik haavata ja solvata (Kulemzin \& Lukina 1973: 36; Kulemzin \& Lukina 1990: 180). Vladislav Kulemzini ja Nadežda Lukina uurimusest ilmneb, et Suur-Jugani jõel ohverdati valged põdrad Tjoras-nai a ykile, kõigi tulede emale, kelle nime nad kirjutavad kujul tšuras nai angki (Kulemzin \& Lukina 1992: 93). Kuigi tänapäeval Juganil enam põtru pole ja neid ei ohverdata, rääkis P.K. meile:

Kui tuuakse ohvreid Tjoras-nai ankile, sü̈̈atakse tuli tikkude abita. Tjoras-nai anki on veel tähtsam kui [vana maaema] Muix- 
anki. Varematel aegadel pidasid nad Muix-ankit Tjoras-nai tütreks.

Tjoras-nai a pki on kõige esimene olend, kõigi muutuste ema. Sellest usust tuleneb tema seotus kahe elemendi, tule ja veega, mille vormitus on iidsetest aegadest peale muutumisi esile kutsunud. Handi maailmapildis jagunevad asjad elusateks ja elututeks. Elusad asjad, nagu inimesed, loomad, puud, tuli, äike, välk ja vaimud, saavad sünnihetkel a pki Pugoselt animeeriva hinge $l i \hbar$. Kui laps sünnib surnult, tähendab see, et tal puudus lił(Kulemzin 1976:41-42). P.K. ütles, et

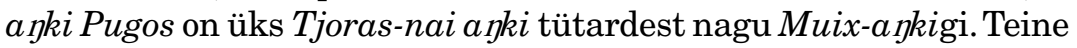
asi, millest P.K. rääkis, on see, et Muix-a ฤki on üks kolmest tütrest, kellest igaüks on seotud ühega maailma kolmest mõõtmest. ${ }^{8} A \eta k i$ Pugos on seotud taevamaailmaga, Muix-a pki maapealse ilmaga ja viimane õde allilmaga, nii et oma tütarde kaudu, kes on tema enda eri aspektid, on Tjoras-nai a pki olemas ja tegutsemas kõigis maailmades. Semiootiliselt on kõik maa, vee ja tulega seotu handi maailmapildis naiselik elu edasiandmine erinevates vormides.

Tjoras-nai a pkit esindava kase lähedal asub Musta Tõvemehe plekk-kuju, sõnasõnaline tõlge handi fraasist puixt iki, mis on kyp hu yi, haigusevaimu epiteet (Kulemzin 1978: 12 jj). Mõlemad on vormid nimest Kul, keda Vahhi ja Vasjugani jõe handid peavad Torumi kõige vanemaks pojaks, kes saadeti maale selleks, et maad rahvastada. Kui inimesi sai liiga palju, lahkus ta siit allmaailma ja hakkas nende arvu vähendama, saates vaime maa peale haigusi levitama ja süües inimeste südameid (Kulemzin 1976: 31). Kuli kui esiisa roll on kahetine, sest tema rivaalitsemise olemusest Torumiga on eri pärimusrühmades erinevalt aru saadud. ${ }^{9}$ Ühes inimese päritoluloo variandis pannakse kul kyg huji teeneks ka inimeste loomine, mitte ainult paljundamine, kuigi see sündis Torumi käsul (Kulemzin 1976: 45). Tihtipeale peetakse loomade tekkimist Torumi teeneks, aga inetute ja ebameeldivate asjade teke pannakse Kuli süüks (Kulemzin 1984: 163).

Kul tähistab kala, teda tuntakse nime all kul tete $k u$ ehk kul tete łu (Kalalooja Mees ehk Kalalooja Vaim). Seetõttu on tema sümboliks suur kala: ühes müüdis samastatakse ta tuuraga. Tavapraktika seostab teda ka haugiga, eriti vana "sarvilise" haugiga, kuigi haug võib olla vaid üks tema paljudest esinemisvormidest. Ka peetakse teda jõgede ja järvede üldiseks kaitsjaks. Keeleteadlased on võrrelnud paljudes soome-ugri keeltes esinevat algsoomeugri sõna *kolja, millel 
Olga Balalajeva, Andrew Wiget

on sellised tähendused, nagu 'kuri vaim, koletis, katk, vesideemon' (Ajkhenvald \& Helimski \& Petrukhin 1989: 155).

Handid usuvad, et loomad on maa peale lahti lastud maa alt (Kuli valdustest) ja osa hante peab taevajumal Torumi ulukijagajaks (s.t mitte niivõrd loojaks). Allmaailmal on ka omad voorused ning Kuli seostatakse metalli, eriti rauaga ja musta värviga (handi puixt). Ka kutsutakse teda Kellox Torumiks, surnute jumalaks. Seega on ta täiesti kohaselt esindatud teda personifitseerivale metallkujule ohverdamise kaudu.

Ohverdusse on kaasatud veel kaks jumalust, Torum ja Kon-iki, kes kuuluvad handi peajumalate hulka. Mõnede obiugri müütide järgi on Torum taevast visatud naise Tjoras-nai a pki poeg, teisel juhul on Torum Tjoras-nai a pki kaasa, kes ta taevast alla viskas. Mõlemal juhul on Kon-iki Tjoras-nai a pki poeg, kes elab eeterlikus riigis oma ema maapealse ilma ja isa taevase ilma vahel. Seoses päikesekultusega on ta Torumi seitsmes, noorim poeg, teda teatakse nime all Mir-susne-xum ehk Maailma Valvav Mees, sest ta liigub päikese kombel üle taeva ning hoiab ja kaitseb inimesi (Toporov 1989). Torumi ja loomade suhteid kajastav traditsioon varieerub paikkonniti. Mõnel juhul on Torum loonud kõik, kaasa arvatud loomad, ja seejärel lahkunud sellest maailmast (Kulemzin 1976: 32-33, 45), pannes valitsejakohustused Kon-iki peale. Muude versioonide puhul jättis ta elusolendite loomise oma vanema poja $K y \eta$ łu ij peale, aga pidi pärast saatma maa peale haigused, et loodut ei saaks liiga palju (Kulemzin 1976: 31).

Myril väljendub Torumi ja Kon-iki kohalolek hüüetes päikese poole. K. F. Karjalainen hindas palve tähendust minimaalseks:

Mingil määral kasutatakse palveid, aga see on vaid osa ohvritseremooniast ja sisaldab ainult vajaduste ja tahtmiste üleslugemist (Karjalainen 1995: II 96).

Ometi ütles meie handist informant K.K., et see palve on midagi enamat kui lihtsalt kaasnähe, toetades V. Kulemzini kinnitust (1984: 114), et handid palvetavad Torumi poole Kon-iki kaudu:

[Iga kord] kui muhta-ku räägib, ütleb ta samu sõnu, aga lujid on erinevad. Põdrad jaotatakse suuruse järjekorras, kõige suuremad kõige suurematele tuyidele kuni kõige väiksemateni välja. Kui põtru on palju, saab iga luy kaks või kolm põtra. 
Alati palvetatakse kuu ja päikese poole. Kon-iki isa [Torum] on olulisim. Ta ei suhtle kunagi inimestega otse; ta on lihtsalt liialt hõivatud kirjutamisega. Kon-iki kaitseb maakera [vene $\mathrm{k}$ šar zemnoi]. Palves palutakse head elu ja õnne.

K.K. vihjas, et selles palves esineb nii individuaalse kui ka kollektiivse palumise mõõde:

Kui oled põlvili, siis palud midagi. Pöörad ennast ümber kolm või seitse korda.

Kui kahesus aitab meil osaliselt mõista, miks on Torum ja ky 7 łu mõlemad sellesse ohverdusse kaasatud, on siiski tarvis pisut lahata ka handi eshatoloogiat, et mõista, kuidas rituaal kindlustab majandusliku heaolu, mõjutades põhjapõtrade taastootmist. Nagu eespool mainitud, on hantide maailm jagatud elavaks ja elutuks. Igal elusolendil on mitu hinge: meestel viis, naistel neli, loomadel kaks. Kui hingede mitmesus obiugrilaste juures on etnograafe alati huvitanud, siis on antud teema juures kõige tähtsamaks peetud asjaolu, et loomade kaks hinge - lił ja $i t s$ - esinevad ka inimestel ning paistavad olevat handi hingekujutelma põhielemendid (Wiget \& Balalaeva 1995). Lühidalt öeldes on lił hingushing, mis seostub indiviidi iseloomu ja elusolekuga; ta võib reinkarneeruda. Its on varihing, mis seostub nähtava vormi ja välimusega; see on sõltumatu individuaalsest $l i$ fist ja käib kaasas kehaga.

Valeri Tšernetsov (1987) lahendas kõnealuse kujutelma arenguloo, leides, et pärast surma läheb lił tagasi Torumi juurde, et saada uuendust, ja $i$ ts läheb Kuli juurde allmaailma, et reinkarneeruda (Kulemzin 1984: 21). K. F. Karjalainen märkis, et

[---] vaimudele saadetakse just ohverdatud looma ils. "Me tapsime põdra teie pärast. Võtke iłs ja vaadake tema peale oma järvesuuruste silmadega," on ohverdamisaegne palve (Karjalainen 1995: I 39).

Mis puudutab handi eshatoloogiat, siis olemasoleva teabe põhjal on võimalik rekonstrueerida handi uskumus, et loomine seisneb nende kahe hinge, eluhinge ja kehahinge kokkusulatamises algmateeriaks. Handid usuvad, et a $7 k i$ Pugos paneb elustava hingushinge $l i \hbar$, mille ta saab Torumilt, sünnihetkel elavate olendite sisse (Kulemzin 1976: 39). Samamoodi ilmneb, et Muix-a ฤłki (või ka Tjoras-nai a Đki kolmas 
Olga Balalajeva, Andrew Wiget

tütar) annab neile $i l s i$ ehk Kulilt (kelle juurde need pärast surma lähevad) saadud hinge, et valmistada keha ette uueks olekuks. Sellest hetkest peale elab elusolend maapealses ilmas, ta on saanud vormi, isikupära ja hinge kahe üheaegse paralleelse protsessi kaudu. Selles osaleb loomise ajal mees- ja naisjumalast paar, kusjuures üks paariline tegutseb taevailmas (Torum või a pki Pugos), teine allmaailmas (Kul või Muix-a ฤki) (Wiget \& Balalaeva 1995).

Mõistes ühest küljest Torumi ehk a gki Pugose ja teisest küljest Kuli ehk Muix-a Đki rolli loomade taastootmisel, mõistame ka kasepuu toitmise ja Musta Tõvemehe tähendust. Selle traditsiooni iidsust tõendab K. F. Karjalainen, tsiteerides Alexandre Guagnino tähelepanekuid põdraohverdamisest 1587. aastal:

Obdorski ugrilased ja vogulid tapavad "valitud põdra, kelle verega nad määrivad pühaku suud, silmi ja teisi kehaosi” (Karjalainen 1995: II 98).

Tema enda uurimuse kohaselt aga

[---] siis, kui šamaan ohverdab vaja-artt-kule, 'ulukijagajale mehele', ütleb ta: "Suur Torum, söö! Ema Maa, söö! Jne" (Karjalainen 1995: II 206).

Kui võtta kokku kõik kultuselemendid, nagu loomanahkade panemine kase otsa rituaali lõpus, lihatombud kasepuu küljes ja Musta Tõvemehe kuju, siis ilmselt lavastavad need sidepidamist Torumi ja Kuliga eesmärgil, et viimased saadaksid inimestele põtrade kujul liha.

Pärast ohvriloomade peiesid jätkub inimeste koostöö taastootmisel. Tširta-ku luges palve Tjoras-nai a Đ kile ja puudutas punase rätikuga otsaesist kõigil, kes olid Uue Tulega süüdatud lõkke ümber kokku tulnud, samuti väljastpoolt tulijatel, et kindlustada järgmiseks aastaks tuli igasse kodusse. K.K. andmetel

[---] tuli on esimene nähtav luy; me isegi suudleme punast rätti, et talle meie kõigi kohalolekust märku anda.

Seejärel rühm lahknes vastavalt soole ja kohalviibivad mehed jagasid ohverdatud loomade liha.

Mehe ja naise koostöö on selgelt nähtav ka ohverdatavate esemete paigutusest. Handi komme riputada nahad ja kondid puu otsa osutab uskumust looma hinge tagasipöördumisest Ulukihoidja ehk 
Loomade Isanda poole, kes annab neile uue liha ja saadab maa peale tagasi, et kindlustada inimeste hüvesid (Kulemzin 1984: 162-163). See kontseptsioon ilmneb ka K. F. Karjalaise poolt väljatoodud mõistes 'hinge kate':

Sellel eesmärgil riputatakse puu otsa pea koos kapjadega, sest usutakse, et kui hing on kehast eraldi, on ta ikka veel alles peas ja kapjades. Sellest vaatepunktist on Surguti rajoonis tavaks eemaldada hinge kate ohvriloomalt, mis tähendab vaid tema hinge (mitte keha) ohverdamist vaimule samal ajal, kui loom jääb teenima lihaohvri toojat (Karjalainen 1995: II 102).

Pimi handist informandi K.K. tähelepanekute kohaselt on nahad riputatud puu otsa ja lunid võtavad põhjapõdra, kes on neile mä̈̈ratud. P.K. kinnitab sama:

Põdranahad riputatakse puu otsa, et nende kaine [üks hinge liike] üles läheks ja jumal selle endale võtaks. Inimesed palvetavad, et jumal võtaks loomade hinged hästi vastu.

K.K. interpreteeringust ämbri ja salli paigutuse kohta männi jalamil oli juttu eelnevalt.

Kui kaselatv, kuhu põdranahad riputatakse, seostub Tjoras-nai a pkiga, siis männipuu Tareni, haavava vaimuga, kes võib tungida inimese sisse nii, et viimane kaotab kontrolli ja muutub vägivaldseks, kakleb ja vigastab (haavab) teisi inimesi. See vaim kutsub esile ka õnnetusi ja enesetappe ning on haiguste ja sõdade taga (Kulemzin 1984: 54). P.K. ütles, et Taren on suurim ja vanim jumal, kuigi üllataval kombel selgus, et Põhja-Obi ääres ei peeta Tareni mitte meessoost, vaid naissoost jumalaks. Suhe Tareni ja Muix-a pki vahel on ebaselge, kuigi nende vahendid ja teguviisid näivad tähendavat naiselemendi ehk söögitegemisala maapealset paigutust ohverduse korral, niisamuti nagu põdranahkade puulatva riputamine tähendab meeselemendi ehk jahiala paigutust.

On selge, et myr kindlustab majandusliku heaolu sellega liitujatele, tugevdades kogukonna vaimu, milles tapmine ja lihatarbimine on ette nähtud kahepoolseks suhtlemiseks jumalatega, kes taastoodavad inimesi ja loomi, keda inimesed tapavad ja söövad. Sellises suletud süsteemis tagab surmatud looma $i$ lsi eest hoolitsemine, et see tuleb uuesti maa peale liha tootma. Niisugused uskumused on levinud põhjarahvaste kohalikes kütikultuurides. Küsimuse muudab keerulisemaks asjaolu, et ohvriloomad on kodustatud. On siiski tõe- 
Olga Balalajeva, Andrew Wiget

näoline, et idahandid, nagu ka teised, kes adapteerivates protsessides osalevad, suutsid ise leida jahinduseks ja kalanduseks, samuti uskumusteks, eriti põhjapõdrajahiga seotud rituaalideks vajalikud vahendid (handi woya) (Kulemzin 1984: 86-87), millest mõni võis olla juba nii kohandatud, et aitas rakendada põhjapõtra kodumajanduses ja ohverdada kodustatud põhjapõtru. Need võisid hõlmata koljude, sarvede ja luude asetust rituaalis, ka võis sinna kuuluda vere, teatud organite ja kindla osa liha kogumine ning liha rituaalne laialijagamine, samuti osalejate soost johtuvad keelud ja osalustavad. Ajaloolised selgitused Surguti rajooni hantide koduloomade - hobuste, lehmade ja põtrade - ohverdamisest Woya-Ort-ikile, Ulukijagajale, toetuvad K. F. Karjalaineni 20. sajandi alguse vaatlustele (Karjalainen 1995: II 206, 233).

\section{Kultustegelased ja mugandavad suundumused}

Üks märkimisväärsemaid elemente meie nähtud rituaalis oli kultustegelaste rolli märgatav erinevus sellest, mida on kirjeldatud etnograafilises kirjanduses. Rääkides väljastpoolt tulijatega vene keelt, viitavad handid harjumuspäraselt mõnele või kõigile "šamaani" rollidele ja nendega seotud tegevustele, mis samastuvad "šamanismiga", kuigi enamik rolle ei peegelda Siberi šamanismiga seostatavaid üldiseid jooni.

Tuginedes neljakümne aasta tagustele välitööde andmetele on V. Kulemzin 1976. aastal kirjeldanud idahandi kultustegelaste rolli üsna kategooriliselt, alahinnates silmanähtavalt konsolideerimismärke. Näiteks ühe tegelase, arehta-ku ehk laulutundja funktsioon on paralleelne mante- $k u$ omaga ja langeb paljuski kokku tširta-ku rolliga. Põhimõtteline erinevus on see, et arehta-ku ei kasutanud kordagi trummi (buben), vaid viis šamaanirituaali läbi keelpilliga (narkas-juhh ehk panan-juhh). Mõnedes kogukondades tunti nii keelpilli kui ka trummi, aga eelistati keelpilli. Bubeni ja narkasjuhhi geograafiline levik on tähendusrikas. Obi keskjooksu lõunaosas kasutati šamaanirituaali ajal keelpilli, kusjuures Jugani ja SalimBaliki jõgikonnas ei tuntud trummi üldse. Samal ajal ei tuntud keelpilli põhjas, kõrgmaastikul, mis eraldab Kesk-Obi taiga handid metsa- ja tundraneenetsitest. Samas kasutati Obi põhjaosas ja Vasjugani hantide hulgas mõlemaid pille ja šamaani õpilased, kes alustasid panan-juhhiga, jätsid selle siis kõrvale, kui said tširta-kuks 
ja vahetasid keelpilli trummi vastu. Selline olukord võimaldab kultustegelase rolli ümberdefineerida, kui võtta aluseks V. Kulemzini omadest erinevad kriteeriumid.

Hinnates erinevust kõrgemalt kui ühtsust, vähendab V. Kulemzin võimalust väärtustada neid muutusi kultustegelase rollis, mille tunnistajaks meie myri ajal olime. 1976. aastal eristas V. Kulemzin idahandi kultustegelastel seitse rolli. Kaks neist olid tähtsad selle myri korraldamisel, kus meie viibisime: multe- $k u$ (mante- $k u$ ) ja tširta$k u$.V. Kulemzin kirjeldab multe-ku rolli põhiliselt kui lugude jutustaja rolli (loomulikult teame selliseid isikuid, nagu P.K., kes sellele kirjeldusele vastavad ja kes seda tiitlit tunnustavad). V. Kulemzin lisab, et multe-kud tuntakse ka kui inimest, kes oskab jumalatega rääkida ja võib seetõttu funktsioneerida kui preestri ja tseremooniameistri kombinatsioon, s.t ta mitte ainult ei juhata palvusi, vaid ka korraldab ja juhendab rituaali läbiviimist. Lõpuks märgib V. Kulemzin, et mõnel pool on multe-ku veel nii ennustaja kui ka ravitseja seisuses, kuigi mõlemad rollid on teisejärgulised. Rituaalis, millest meie osa võtsime, oli multe-ku (Pimi jõe hantide dialektis muhte-ku) rituaali korraldaja, isik, kelle tegevus on ühe päeva pikkuses põdraohverdusrituaalis kõige nähtavam. K.K. järgi on muhte- $k u$ isik,

[---] kes teab sõnu, mida siis öelda; paljud neist rä̈ägivad (voolavalt), nagu jutustaksid nad lugu, kuid mõned ei suuda isegi sõnu välja hääldada.

Sellel ohverdusel, kus meie viibisime, olid multe-ku rollis A.M. ja tema vanem poeg. Trom-Agani jõe ääres elavatel hantidel on multe$k u$ roll kestev, seda võib täita rohkem kui üks inimene, ja oli selge, et A.M. oli oma poja kaasanud selleks, et teha temast enda järglane. Ent see positsioon ei paista nõudvat mingeid muid V. Kulemzini loetletud tingimusi (lai juturepertuaar ning ennustamise ja ravitsemise oskus).

Teine tähtis osa on tširta-kul. Nagu nähtub kirjandusest, on tema roll idahantidel kõige lähemal Siberi šamaani omale: ka tema saab oma kutse jumalate kingitusena, sõltub trummist ja erinevatest trummilöömistehnikatest, langeb lovesse ja kannab erilisi rõivaid. Pimi jõe handist informant K.K. ütles, et üliselt on tširta-kul oma isiklik laul, mida ta saadab trummiga; ta võib ka lihtsalt trummi lüüa, ja pärast trummilöömist jutustada oma nägemusest või kontaktist, mis tal trummilöömise ajal tekkis. K.K. sõnul tširta-ku 
Olga Balalajeva, Andrew Wiget

[---] teab, kuidas jumalaga ühendust saada, aga ainult siis, kui ta trummi lööb, jõuavad tema sõnad trummi kaudu jumalani.

Tehes vahet üleüldisel teadmisel ja omaenda spekulatsioonidel, jätkas K.K., kasutades tavalistele hantidele omast väljendit, et $t$ širta$k u l$ on tee jumala juurde, oletades, et laulus läheb ta tegelikult hu juurde või tuleb un sama teed pidi tema juurde. Tširta-ku roll polnud päevapikkusel ohvrirituaalil eriti märgatav. See tuli nähtavale vaid kärbseseene-šamanismi ajal ja ennustamises, mida kuulsime kui osa ettevalmistavatest riitustest, ja õhtul ohverduse järel.

Nähtud ohverdamisrituaalil erinesid mõningad tširta-ku toimingud varasematest etnograafilistest kirjeldustest. Peaasjalikult tema tugev sõltuvus kärbseseenest kui sõidukist tulevikku. V. Kulemzin märgib rolli nimetusega pankal-ku (kärbseseenemees): pärast seda, kui ta oli ära joonud kärbseseeneleotise ja magas, tulid inimesed tema juurde ja kuulasid, mida ta loves viibides rääkis (Kulemzin 1976: 60). Kärbseseene mõju all ennustamine kuulus ka pankal-ku pädevusse ja selle eesmärgiks oli leida haiguskolded inimese kehas, et need eemaldada, või määratleda unes haiguse põhjused. Kuigi kärbseseent tuntakse ja kasutatakse Obi keskjooksul laialdaselt kui sõidukit tulevikku, ei kasutanud ükski meie informantidest sõna pankal-ku. Võimalik, et toimingud, mis olid varem seotud ainult selle rolliga, on hakanud hajuma. Võib ka tõsi olla, et pankal-ku ja tširta$k u$ rollid sulavad praegu ühte, mida võib oletada selle ennustamise järgi, mis toimus ööl enne ohverdust.

Kui viimane väide peab paika, võib olla tegemist idahandi kultustegelaste rollide pika ühtesulamisprotsessiga. Mõned rollid, nagu hoolikalt viimistletud arehta-ku, võivad olla keerukalt põimunud ajalooga. Kindlasti on jätkuvad kontaktid neenetsitega ja neenetsi trummišamanismi ajalooline mõju olnud keelpillitraditsioonile pideva akultureeriva surve allikas. On ka võimalik, et see tuleneb 20. sajandil muudest faktoritest. Üks oluline põhjus oli enne nõukogude aega sündinute, metsas kasvanute ja õppinute põlvkonna kadumine. Nad on asendunud (kuid mitte enam kauaks) 1920.-1930. aastatel sündinute põlvkonnaga, kes allutati mitut liiki akultureerivale survele, nagu kollektiviseerimine, internaatkool ja sõjaväeteenistus. Teiseks ei saa tähelepanuta jätta ka Obi ümbruse looduses asetleidnud muutusi, mis on põliselanikud kodust ära viinud (näiteks Jaun Jahhi handid). Informantide jutu järgi on eepiline ja müütiline laulutraditsioon kõigist idahandi kogukondadest kõige paremini säilinud Obi 
hantidel ja nende seas on ka arehta-ku rolli kehastajaid kõige arvukamalt. Siia võib lisada meie uurimuse laialt levinud traditsiooniteadlikkuse allakäigust 1950.-1960. aastatel sündinute seas, eriti selles osas, mis puudutab handikeelset suulist ja kirjalikku jutu- ning laulurepertuaari. Teadmiste kadumist võib pidada ka nii arehta-ku kui ka multe- $k u$ rolli kehastajate vähenemise põhjuseks. Mõned neist, nagu pankal-ku, on ilmselt lakanud olemast eraldi kultusspetsialisti roll ja neist on säilinud vaid mõned populariseerunud käitumisjooned. Sellist populariseerumist võib seletada mitut moodi, ka sellega, et puudub vajadus luua keerulisi handikeelsete lausete või pillide komplekse.

\section{Kokkuvõte}

Kõnealune protsess on süüdi handi traditsiooniliste uskumuste ja usulise praktika laostumises. Venelaste rünnak handi pühamutele 18. sajandil ja nõukogude ateismikampaaniad, mille käigus kiusati taga šamaane, olidki võtnud traditsiooni hävitamise oma peamiseks eesmärgiks. Muud tegurid, nagu ümberasustamisstrateegia ja keskkonna hävitamine seoses naftatööstusega, on oletatavalt põhjustanud kaudseid konflikte. Nendes väidetes on küll mingil määral tõtt, aga ohverdamisrituaal, mille meie üles tähendasime, tõendab, et jutud handi traditsioonilise usulise praktika väljasuremisest on siiski enneaegsed.

Kultuurilisel püsimajäämisel on palju faktoreid (Rushforth \& Chisholm 1991). Kuigi meie kirjutise raamesse ei mahu kõigi nende mehhanismide kirjeldamine, mis tulevad arvesse Surguti rajooni põhjaosas elavate idahantide kollektiivse põhjapõdraohverduse säilimisel, on mitmed neist mainimist väärt.

Esiteks on neil pidev kontakt neenetsitega, kellega sõlmitakse aeg-ajalt segaabielusid. Neilt on handid sajandeid tagasi üle võtnud põhjapõdrakasvatuse ja nemad on kõigi selle tegevusalaga seotud uuenduste allikas. Teiseks, vaatamata sellele, et põhjapõdrakasvatus on üle võetud neenetsitelt, on põhjapõdrast saanud hantide kultuurilise eristumise sümbol domineeriva vene kogukonna silmis. Suurema panuse idahantide põhjapõdrakasvatusse ja põhjapõdraohvrisse võis anda nn Kazõmi sõda 1930. aastatel (Golovnjov 1995), 


\section{Olga Balalajeva, Andrew Wiget}

kui nõukogude võimu püüded peale suruda kollektiviseerimist ja põhjapõtrade ümberjagamist kutsusid esile Kazõmi jõe ääres elavate hantide vihase vastuhaku.

Risti vastupidise identiteedi pealesurumine minevikus on tänapäeval põimunud kohaliku omavalitsuse ametnike positiivse stereotüübiga - nad tulevad ametlikel puhkudel iirile ja juhatavad hantidest huvitatud külalisi paikadesse, kus on suured, maalilised põhjapõdrakarjamaad. Naftatootmise arendamise õhkkonnas on põhjapõder muutunud kohalikes arutlustes tööstusest võitluse ikooniks handid räägivad sageli mürgitatud põhjapõtradest ja valitsusametnikest, kes omakorda osutavad sageli hoopis traditsiooniliste hantide ja nende põhjapõtrade elujõule. Kolmandaks, ohverdusrituaal, mille tunnistajaks olime, tõi kokku palju omavahel suguluses olevaid perekondi, kes olid koondunud ürituse algataja ja tširta-ku, Kazõmi põdrakasvataja poja A.M-i ümber. Tema isa võttis osa Kazõmi sõjast ja kolis hiljem Trom-Agani jõe ülemjooksule. K.K. tunnistus osutab samuti kohalike suguluses olevate perekondade kogukonnale kui kõnealuse tava elushoidmise sotsiaalsele mehhanismile.

Kuigi kollektiivne põdraohverdamine on säilinud, tundub see olevat ka muutunud. Üks mõeldavaid võimalusi peitub K.K. arutelus vaimu motivatsioonist kolmes myris, millel ta on osalenud: myri läbiviimine on tänapäeval motiveeritud mitmesuguste asjaoludega. Kuigi ajaliselt võib myri korraldada endiselt hilissügisel või varakevadel, tundub selle seotus kalanduse ja jahindusega ebaselgem, see on koormatud teistest motiividest, mida on sageli raske kindlaks teha. Nüüdisaegsed ülestähendused, ka käesolev, märgivad suurenenud rõhuasetust kärbseseente mõjul ennustamisele, mis on selgeks raamiks ohverduspäeva formaalsele tegevuskavale. Üheks muutuseks on ka tširta-ku ja pankal-ku rolli kokkusulamine.

Lõpuks, me pole kunagi lugenud ega kuulnud myrist, mis oleks võrreldav sellega, kus meie viibisime. See oli erandlik juhtum nii arvude (osavõtjaid üle 60, ohverdatud põtru 11) kui ka terviklikkuse poolest. Võib püstitada hüpoteesi, et sotsiaalse ja keskkondliku surve ning naftatööstuse tingimustes on myr saanud idahantide kultuuriliste funktsioonide kõige kandvamaks osaks ja see ilmneb kultuse läbiviimise komplekssemaks muutumises. Võib ka arvesse tulla, et myr säilib edaspidigi, sest see lavastab handi maailma põhisuhteid ja nõuab jätkuvalt rituaalist osavõtjatelt, et nad taastoodaksid uskumusi ja nendega kaasas käivaid toiminguid.

Tõlkinud Maarja Villandi 
Olga Balalajeva, Andrew Wiget

\section{Kommentaarid}

${ }^{1}$ Autorid avaldavad tänu John D. ja Catherine T. MacArthuri Fondile käesoleva kirjutise aluseks olevate hooajaliste välitööde toetamise eest 1994. aastast tänaseni. Autorid on tänulikud kommentaaride eest nendele inimestele, kes kuulasid meie ettekannet antud artiklist 1995. aastal Jyväskyläs VIII soome-ugri kongressil ja 1999. aastal Moskvas peetud rahvusvahelisel šamanismikongressil, mida toetas Vene Teaduste Akadeemia Antropoloogia ja Etnograafia Instituut, samuti artikli käsikirja retsensentidele.

${ }^{2}$ Nende rahvaste ametlik nimekiri on avaldatud ajakirjas Mir korennõhh narodov: Živaja Arktika 2000. aasta 3. numbris ilmunud Vene Föderatsiooni valitsuse otsuses 24 . märtsist 2000 Jedinõi peretšen korennõhh malotšislennõhh narodov Rossiiskoi Federatsii (Jedinõi peretšen 2000). Ülevaateid handi kultuurist vt Levin \& Potapov 1956; Kulemzin 1984; Kulemzin \& Lukina 1992; Balzer 1994; Golovnjov 1995. Etnograafilis-ajalooliselt on väärt teos ka M. M. Balzer 1999. Varasemad 20. sajandil ilmunud asjakohased teosed: K. F. Karjalainen 1995 (esitrükk 1922) ja V. Tšernetsov 1987, 19. sajandi teisest poolest M. A. Castrén 1860, Gondatti 1888b, S. Patkanov 1999 (esitrükk 1884) ja A. Dunin-Gorkavitš 1995 (esmatrükk 1904).

${ }^{3}$ Respekteerides nende hantide privaatsust, kes autoritele infot jagasid, oleme otsustanud neid nimetada ainult initsiaalidega. Külastasime K.K-d tema stoibištšes (suurpere elupaik) Ai-Pimi jõel juunis 1995 ja juunis 1996 ning intervjueerisime teda mõlemal korral. Autorid tegid välitöid Jugani jõe piirkonnas koos P.K-ga ja käisid tema stoibištšes igal suvel alates 1994. aastast. Handid J.S. ja B.N., keda autorid külastasid ja küsitlesid 1994. aastal, elasid Trom-Agani jõe ääres.

${ }^{4}$ Põhjarahvaste karukultuse käsitlused alustades klassikast (Hallowell 1926) on laialt tuntud. Tähtsamaid arutelusid sellistest tegevustest võib leida N. Gondatti (1888a), V. Kulemzini (1972) ja É. Schmidti (1989) uurimustest.

${ }^{5}$ Aleksei Zenko (1997) on väitnud, et kollektiivsed ohverdamised on kõrgema staatusega kui individuaalsed, aga tekstist ei selgu, kas seda väidab autor või väidavad seda handid, ka puuduvad tõendid selle väite kinnitamiseks. Me pole välitöödel ega vastavas kirjanduses leidnud sellele väitele ühtegi toetust.

${ }^{6}$ K. F. Karjalainen ei nõustunud B. Munkácsi väitega, et hobuse ohverdamine on põliskomme, ta pidas seda hoopis tatari mõjuks (Karjalainen 1995: II 100).

${ }^{7}$ See teema võib ainet pakkuda nii aastatuhandelõpu kui ka kristlikele apokalüptilistele interpretatsioonidele. Meie märkmetes on kirjas P.K. 


\section{Olga Balalajeva, Andrew Wiget}

mõttekäik: Ta ei tea, kas veeuputuse põhjustas Tjoras-nai anki või tema tütar. Hantidel on kombeks rääkida, et veeuputused ja tulekahjud juhtuvad iga 2000 aasta tagant, viimane oli peaaegu 2000 aastat tagasi (ta arvestab 20. sajandi lõpust). Ka kuulis ta, et inimesed teevad pattu ja jumal põletab nende patud ja peseb seejärel nad veeuputusega üle. Tema arvates aastal 2000 tõenäoliselt veeuputust ei tule, aga võib tulla midagi muud.

${ }^{8}$ Kuna on ebaselge, kas Tjoras-nai apkil on kolm tütart või on ta üks kolmest õest, ei ole üllatav, et jumaluste genealoogiline suhe on hägustunud paikkondlike erinevuste, traditsiooni puuduliku tundmise või muude asjaolude tõttu. Samasugune ebaselgus ilmneb Kuli ja Torumi ning Kuli ja Kon-iki suhetes.

${ }^{9}$ Ühes teises müüdis tuntakse teda Torumi vanema vennana, kusjuures mõlemad vennad sündinud maaemast a pki Pugost. Tema antagonismi taeva võimule on esitatud mitut moodi, olenevalt genealoogilisest mudelist, mis sõltub kohalikust mütoloogiast. Kui pidada Kuli Torumi pojaks, on tema rivaaliks Torumi teine poeg, Kon-iki. Kui pidada Kuli Torumi vennaks, on tema rivaaliks Torum ise.

\section{Kirjandus}

Ajkhenvald, Alexandra \& Helimski, Eugen \& Petrukhin, Vladimir 1989. On Earliest Finno-Ugrian Mythologic Beliefs: Comparative and Historical Considerations for Reconstruction. Mihály Hoppál \& Juha Pentikäinen (toim). Uralic Mythology and Folklore. Budapest: Ethnographic Institute of Hungarian Academy of Sciences, lk 155-160.

Balalajeva 1999 = Балалаева, Ольга. Священные места хантов Средней и Нижней Оби. Ольга Балалаева \& Эндрю Вигет (= Andrew Wiget) \& Елена Главацкая (koost). Очерки истории традиционного землепользования хантов: Материалы к атласу. Сборник статей. Тезисы. Екатеринбург, lk 139-156.

Balzer, Marjorie Mandelstam 1994. Khanty. Paul Friedrich (toim). Encyclopedia of World Cultures. Boston: G. K. Hall, lk 89-92.

Balzer, Marjorie Mandelstam 1999. The Tenacity of Ethnicity: A Siberian Saga in Global Perspective. Princeton: Princeton University Press.

Castrén 1860 = Кастрен, Матвей-Александр (Матиас Александер). Путешествие по Лапландии, Северной России и Сибири (1838-1844, 1845-1849 гт.). Магазин землевладения и путешествий: Геогр. сб. Н. Фролова 2. Москва.

Dunin-Gorkavitš 1995 = Дунин-Горкавич, Александр. Тобольский Север: Общий обзор страны, ее естественньх богатств и промьшленной деятельности населения I. [Uustrükk väljaandest: Дунин-Горкавич, А. А. Тобольский Север: Общий обзор страны, ее естественных богатств и промышленной деятельности населения I. Санкт-Петербург 1904]. Москва: Либерея. 
Golovnjov 1995 = Головнев, Андрей. Говорящие культуры: Традиции самодийцев и угров. Екатеринбург: Институт истории и археологии Уральского Отеления PAH.

Gondatti 1888a = Гондатти, Николай. Культ медведя у иного-родцев СевероЗападной Сибири. Труды Этнографического отделения Императорского Общества любителей ествествования, антропологии и этнографии при Московском университете XLVIII: 2, lk 74-87.

Gondatti $1888 \mathrm{~b}=$ Гондатти, Николай. Следы языческих верований у инородцев Северо-Западной Сибири. Москва: Типография Е. Г. Потапова.

Hallowell, A. Irving 1926. Bear Ceremonialism in the Northern Hemisphere. American Anthropologist 28: 1, lk 1-175.

Jedinõi peretšen 2000 = Единый перечень коренных малочисленных народов Российской Федерации. Kinnitatud Vene Föderatsiooni valitsuse otsusega 24. märtsist 2000. Мир коренных народов: Живая Арктика 3, lk 48-50 (http://www.raipon.org/russian_site/library/ipw/number3/article14.html 24. september 2003).

Karjalainen 1995 = Карялайнен, Кустаа Фредрик. Религия югорских народов 1-2. Томск: Издательство Томского университета.

Kossarev 1984 = Косарев, Михаил. Западная Сибирь в древности. Москва: Наука.

Kulemzin 1972 = Кулемзин, Владислав. Медвежий праздник у ваховских хантов. Лукина, Надежда \& Томаков, Н. (toim). Материалы по этнографии Сибири. Сборник статей. Томск: Издательство Томского Государственного университета, lk 93-98.

Kulemzin 1976 = Кулемзин, Владислав. Шаманство васюганско-ваховских хантов: Конец XIX - начало XX вв. Лукина, Надежда (toim). Из истории шаманства. Томск: Издательство Томского Государственного университета, lk 3-154.

Kulemzin 1984 = Кулемзин, Владислав. Человек и природа в верованиях хантов. Томск: Издательство Томского Государственного университета.

Kulemzin \& Lukina 1973 = Кулемзин, Владислав \& Лукина, Надежда. Легенды и сказки хантов. Томск: Издательство Томского Гссударственного университета.

Kulemzin \& Lukina $1990=$ Кулемзин, Владислав \& Лукина, Надежда. Мифы, предания, сказки хантов и манси. Москва: Наука.

Kulemzin \& Lukina 1992 = Кулемзин, Владислав \& Лукина, Надежда. Знакомьтесь: ханты. Новосибирск: Наука (Сиб. изд. фирма).

Leete, Art 1997. Sacrificial Ceremony at Lake Num-To. Arctic Studies 1. Pro Ethnologia 5. Tartu: Eesti Rahva Muuseum, lk 35-55. 


\section{Olga Balalajeva, Andrew Wiget}

Leete, Art 1999. Ethnopolitical Comments about the Sacrificial Ceremony at Lake Num-To. Arctic Studies 2. Pro Ethnologia 7. Tartu: Eesti Rahva Muuseum, lk 21-26.

Levin, Maksim \& Potapov, Leonid (toim) 1964. The Peoples of Siberia. Chicago: University of Chicago Press. (Vene keeles Народы Сибири. Москва 1956).

Martõnova 1998 = Мартынова, Елена. Очерки истории и культуры хантов. Москва: Институт этнологии и антропологии им. Н. Н. Миклухо-Маклая Российской Академии Наук.

Patkanov 1999 = Патканов, Серафим. Остяцкая молитва. Тюмень: Издательство Юрий Мандрики.

Pika, Alexander 1999. Neotraditionalism in the russian North: Indigenous peoples and the Legacy of Perestroika. Seattle: University of Washington Press.

Rushforth, Scott \&. Chisholm, James S. 1991. Cultural Persistence: Continuity in Meaning and Moral Responsibility among the Bearlake Athapaskans. Tucson: University of Arizona Press.

Schmidt, Éva 1985. Khanty and Mansi Religion. Mircea Eliade (toim). The Encyclopedia of Religion. New York: Macmillan Pub. Co. \& London: Collier Macmillan, lk 280-288.

Schmidt, Éva 1989. Bear Cult and Mythology of Northern Ob'-Ugrians. Hoppál, Mihály \& Pentikäinen, Juha (toim). Uralic Mythology and Folklore. Budapest: Ethnographic Institute of Hungarian Academy of Sciences, lk 187-231.

Zenko 1997 = Зенько, Алексей. Представления о сверхъестественном в традиционном мировоззрении обских угров: Структура и вариативность. Новосибирск: Наука (Сиб. предприятие).

Toporov, Vladimir 1989. About a Probable Reflection of the Iranian Mitra. Mihály Hoppál \& Juha Pentikäinen (toim). Uralic Mythology and Folklore. Budapest: Ethnographic Institute of Hungarian Academy of Sciences, lk 169-178.

Tšemjakin \& Karatšarov 1999 = Чемякин, Юрий \& Карачаров, Константин. Древняя история Сургутского Приобья. Балалаева, Ольга \& Вигет, Эндрю (= Andrew Wiget) \& Главацкая, Елена (koost). Очерки истории традиционного землепользования хантов: Материаль к атласу. Сборник статей. Тезисы. Екатеринбург, lk 9-66.

Tšernetsov 1987 = Чернецов, Валерий. Источники по этнографии Западной Сибири. Томск: Издательство Томского университета.

Wiget 1999a = Вигет, Эндрю. Экономика и традиционное землепользование восточных хантов. Балалаева, Ольга \& Вигет, Эндрю \& Главацкая, Елена 
(koost). Очерки истории традиционного землепользования хантов: Материаль к атласу. Сборник статей. Тезисы. Екатеринбург, lk 157-200.

Wiget $1999 \mathrm{~b}=$ Вигет, Эндрю. Черный снег: Нефть и восточные ханты. Балалаева, Ольга \& Вигет, Эндрю \& Главацкая, Елена (koost). Очерки истории традиционного землепользования хантов: Материалы к атласу. Сборник статей. Тезисы. Екатеринбург, lk 201-214.

Wiget, Andrew \& Balalaeva, Olga 1995. Khanty Soul Concepts and Shamanism. Paper presented at the International Congress of the Society for the Study of Shamanism. Japan: Nara.

Wiget, Andrew \& Balalaeva, Olga 1997. Black Snow: Oil and the Khanty of Western Siberia. Cultural Survival Quarterly 20: 4, lk 17-19.

Wiget, Andrew \& Balalaeva, Olga 1999. Siberian Perspectives on Protected Use Areas as a Strategy for Conserving Traditional Indigenous Cultures in the Context of Economic Development 2: The Yuganskiy Khanty Biosphere Reserve. Greiffenberg, Tom (toim). Development in the Arctic: Proceedings of the 7th Nordic Arctic Research Forum Symposium. Copenhagen: The Danish Polar Center, lk 88-100. 